\title{
OPENNESS, INCOME-TAX PROGRESSIVITY, AND INFLATION
}

\author{
Joseph P. Daniels \\ Associate Professor of Economics \\ Department of Economics \\ Marquette University, Straz Hall, P.O. Box 1881 \\ Milwaukee, WI 53201 \\ Phone: 414-288-3368; Fax: 414-288-5757 \\ E-mail: Joseph.Daniels@marquette.edu \\ David D. VanHoose \\ Professor of Economics and Herman Lay Professor of Private Enterprise \\ Hankamer School of Business \\ Baylor University, P.O. Box 8003 \\ Waco, TX 76798-8003 \\ Phone: 254-710-6206; Fax: 254-710-6142 \\ E-mail: David_VanHoose@baylor.edu
}

April 5, 2007

\begin{abstract}
$\underline{\text { Abstract }}$
This paper considers a model of an open economy in which the degree of income-tax progressivity influences the interaction among openness, central bank independence, and the inflation rate. Our model suggests that an increase in the progressivity of the tax system induces a smaller response in real output to a change in the price level. This implies that increased income-tax progressivity reduces the equilibrium inflation rate and that the effect of increased income-tax progressivity on inflation is smaller when the central bank places a higher weight on inflation or when there is greater openness. Examination of cross-country inflation data provides empirical support for these key predictions.
\end{abstract}

"We are grateful to Farrokh Nourzad and to David Clark for their helpful suggestions. Nevertheless, we are responsible for any errors. 


\section{OPENNESS, INCOME-TAX PROGRESSIVITY, AND INFLATION}

\section{Introduction}

A significant literature has developed since Romer's (1993) seminal paper exploring the nature of the relationship between the extent of openness to international trade and inflation. Romer's motivation for the negative dependence of inflation on openness observed in cross-country data hinged on the idea that greater openness might worsen the terms of the output-inflation trade-off, thereby reducing a monetary authority's incentive to inflate. This rationale best applies to countries sizable enough to affect international relative prices, and Lane (1997) explored how greater openness can reduce the potential output gains from unexpected inflation in non-traded-goods sectors with imperfectly competitive goods markets and sticky prices. Nevertheless, Temple's (2002) examination of the relationship between openness and sacrifice ratios across a range of nations cast doubt on Romer's proposed explanation of the openness-inflation relationship. Daniels and VanHoose (2007) and Razin and Yuen (2002) offered alternative perspectives indicating that in fact the sacrifice ratio should respond positively to an increased degree of openness, yet inflation nevertheless should decline. Daniels et al. (2005) and Razin and Loungani (2005) have provided empirical support for a positive relationship between openness and the sacrifice ratio, while preserving the predicted inverse relationship between openness and inflation found in the data by Romer and others.

Missing from this literature to date has been consideration of the role that a nation's tax structure likely has on the equilibrium inflation rate. This paper considers an open-economy framework that implies that in a more progressive tax system, the marginal tax rate is more responsive to a given change in real income. Consequently, an increase in real output induced by a rise in the price level raises the marginal tax rate by a larger amount, which reduces the actual rise in output generated by a given 
increase in the price level. This reduces the incentive to increase money growth in an effort to raise the price level in an effort to boost output. Thus, money growth and inflation are lower, ceteris paribus, when the tax system is more progressive.

Our model also indicates that the degree of central bank independence also plays a role in influencing how the progressivity of the income-tax system and openness affect inflation. This is true because central bank independence has its own effects on the latter two variables, thereby conditioning the impacts of variations in income-tax progressivity and openness.

To evaluate the predictions forthcoming from the theoretical model, we consider cross-country data on income-tax progressivity, openness, central bank independence, and inflation. Empirical analysis of cross-country inflation rates provides empirical support favoring the theoretical prediction of a negative relationship between inflation and the progressivity of the income tax system. This analysis also supports the theory's subsidiary implications that greater openness and increased central bank independence both reduce the effects of income-tax progressivity on inflation.

The next section presents our theoretical model and its predictions regarding how income-tax progressivity, openness, central bank independence affect the inflation rate. Section 3 assesses the empirical implications of our analysis and evaluates the evidence. Section 6 summarizes our conclusions.

\section{A Model of the Interplay Among Openness, Progressive Taxation, and Inflation}

The theoretical framework is based in part on the model developed in Daniels and VanHoose (2007). There are numerous atomistic firms, indexed $i$, distributed uniformly along a unit interval. A portion, $\Omega$, of firms have workforces that contractually set nominal wages in advance of labor-market clearing. Spot labor markets determine nominal wages in the portion of firms, $1-\Omega$, that do not have such contracts. Duca and VanHoose (2001) have shown in a closed-economy version of this basic framework that 
if risk-neutral firms and risk-averse workers face common aggregate shocks and heterogeneously distributed firm-specific disturbances, $\Omega$ typically lies between zero and unity but declines as the variability of firm-specific disturbances increases relative to the volatility of aggregate shocks. To maintain tractability, we treat $\Omega$ as an exogenous parameter and thereby abstract from considerations of disturbances that influence the share of firms with nominal wage contracts.

We also consider the competitive limit of the Daniels-VanHoose framework, in which we take into account income taxation. The output produced by a given firm $i$ is (1) $y_{i}=\alpha l_{i}$, where $y_{i}$ is the $\log$ of output and $l_{i}$ is the $\log$ of employment at firm $i$. We abstract from productivity or other shocks that would not influence trend inflation in the standard Barro-Gordon (1983) discretionary-policy framework. The domestic nation's incomeexpenditure equilibrium condition (for a derivation of this Cobb-Douglas approximation, see, for instance, Canzoneri and Henderson, 1991, or Bryson, et. al., 1993) is given by

$$
y=\eta\left(p^{*}+s-p\right)+(1-\beta) y+\beta y^{*}
$$

where $y \equiv \int_{0}^{1} y_{i} \mathrm{~d} i$ is the log of aggregate domestic output; $p \equiv \int_{0}^{1} p_{i} \mathrm{~d} i$ is the log of the aggregate domestic price level; the average propensity to import, $\beta$, is a fraction; $\eta$ is the elasticity of desired spending with respect to the real exchange rate; $p^{*}$ is the log of the aggregate foreign price level; $s$ is the log of the domestic currency price of foreign currency; and $y^{*}$ is the log of aggregate foreign output. Specifying analogous structural relationships for a foreign nation would yield a two-country framework in which $y^{*}$ and $p^{*}$ would be endogenous variables, but here we assume the output and prices abroad are exogenously determined. Henceforth, the foreign money stock, foreign price level, and foreign output are normalized at unity, so that $p^{*}$ and $y^{*}$ equal zero. Finally, domestic income is determined by the quantity equation, 


$$
y=m-p,
$$

where $m$ is the log of the money stock and where the log of velocity has been normalized at a value of zero.

Using (1) in the profit function, $P_{i} Y_{i}-W_{i} L_{i}$, yields the labor demand function for a firm $i$ (with the intercept suppressed because it plays no role in our subsequent analysis):

$$
\text { (4) } l_{i}^{d}=\frac{-\left(w_{i}-p\right)}{1-\alpha} \text {, }
$$

where $w_{i}$ is the log of the nominal wage for the firm.

Workers can consume both domestically produced output and foreign-produced goods. Consequently, labor supply to firms depends on the after-tax real wage computed in terms of the overall price workers pay for a basket of both domestic and foreign goods:

$$
l_{i}^{s}=\lambda\left[w_{i}-(1-\beta) p-\beta s-\tau\right],
$$

where $\lambda>0$ and where $\tau$ is the marginal tax rate applied to workers' wage income, with all revenues collected by the government used to fund the distribution of lump-sum transfers to agents.

For firms with or without nominal wage contracts, the full-information, marketclearing wage satisfies (4) and (5) simultaneously and equals

(6) $\quad \hat{W}_{i}=\frac{[\lambda(1-\alpha)+1] p+\lambda(1-\alpha) \beta(s-p)+\lambda(1-\alpha) \tau}{[\lambda(1-\alpha)+1]}$.

Hence, this nominal wage rate, which is the wage actually paid by firm $i$ if it is among the share, $1-\Omega$, of firms without nominal wage contracts, depends positively on the 
marginal income tax rate. Substitution of (6) into either (4) or (5) and the result into (1) yields output of a noncontract firm with market-clearing $(m c)$ wages:

(7) $\quad y_{i}^{m c}=\frac{-\alpha \lambda \beta(s-p)-\alpha \lambda(1-\alpha) \tau}{[\lambda(1-\alpha)+1]}$.

Thus, output of a firm without wage contracts responds negatively to a real depreciation of the home currency, because this reduces the purchasing power of workers' wages and thereby generates a ceteris paribus decline in labor supply and hence a decline in spot-market employment at noncontract firms. Because a higher marginal tax rate induces a decline in labor supply that requires paying a higher nominal wage, a noncontract firm's output also depends negatively on the marginal tax rate.

For atomistic wage setters within the fraction, $\Omega$, of firms with nominal wage contracts, the contract wage is equal to the expected value of the market clearing wage:

(8) $\quad w_{i}^{c}=\frac{[\lambda(1-\alpha)+1] p^{e}+\lambda(1-\alpha) \beta\left(s^{e}-p^{e}\right)+\lambda(1-\alpha) \tau^{e}}{[\lambda(1-\alpha)+1]}$.

Substituting (8) into (4) and the result into (1) yields output of a firm with wage contracts:

$$
y_{i}^{c}=\frac{\alpha[\lambda(1-\alpha)+1]\left(p-p^{e}\right)-\alpha \lambda(1-\alpha) \beta\left(s^{e}-p^{e}\right)-\alpha \lambda(1-\alpha) \tau^{e}}{(1-\alpha)[\lambda(1-\alpha)+1]} .
$$

Thus, output increases in response to price-level prediction errors, an anticipated real home currency appreciation, or an anticipated cut in the marginal tax rate.

To explore the implications of the structure of a nation's tax system for the relationship between openness, the price-responsiveness of output, and inflation, we follow McCallum and Whitaker (1979), Benavie and Froyen (1986), and Waller and VanHoose (1989) by considering the marginal tax rate function given by

$$
\tau=\tau_{0}+\tau_{1} y
$$


where $\tau_{0}$ is a base level of the marginal tax rate and $\tau_{1}$ determines the degree of progressivity of the tax system. If $\tau_{1}=0$, the marginal tax rate is independent of income, implying a proportional tax system. For $\tau_{1}<0$, the tax system is regressive, and for $\tau_{1}>0$, the tax system is progressive.

Firms behave identically, so that $y_{i}^{c}=y^{c}$ for all $i \in[0, \Omega], y_{i}^{n c}=y^{n c}$ for all $i \in(\Omega$, 1]. It follows that $y=\Omega y^{c}+(1-\Omega) y^{n c}$. Together with the marginal tax rate function in (10), equations (7) and (9) then imply a semi-reduced-form solution for ouput that can be combined with (3) and (2) to determine the semi-reduced forms for the log of the price level and the nominal exchange rate in terms of expected values of the various macroeconomic variables. Substitution of these solutions back in the model then yields a semi-reduced-form expression for aggregate output:

(11) $y=\frac{\eta \Omega \alpha[\lambda(1-\alpha)+1] m-\eta \alpha\left\{\Omega[\lambda(1-\alpha)+1] p^{e}+\lambda(1-\alpha)\left[\tau_{0}+\Omega \beta\left(s^{e}-p^{e}\right)+\Omega \tau_{1}\left(m^{e}-p^{e}\right)\right]\right\}}{\eta[1-\alpha(1-\Omega)][\lambda(1-\alpha)+1]+(1-\Omega) \alpha \lambda(1-\alpha)\left(\eta \tau_{1}+\beta^{2}\right)}$.

This implies that the responsiveness of aggregate output to a change in the domestic price level is given by $\frac{\partial y}{\partial p}=\frac{\Omega \alpha[\lambda(1-\alpha)+1]+(1-\Omega) \alpha \lambda(1-\alpha) \beta}{(1-\alpha)[\lambda(1-\alpha)+1]+(1-\Omega) \alpha \lambda(1-\alpha) \tau_{1}}$, which is directly related to the magnitude of $\beta$. Consequently, as in Daniels and VanHoose (2007), an increase in openness increases the sensitivity of output to a rise in the price level. In addition, this price-sensitivity of output is inversely related to the $\tau_{1}$ parameter and hence to the degree of progressivity of the income tax system. In a more progressive tax system, the marginal tax rate is more responsive to a given change in real income. An increase in real output induced by a given price-level increase thereby boosts the marginal tax rate by a larger amount under a more progressive income tax, which in turn tends to depress to a greater extent the actual output increase that is forthcoming from the given price-level increase. Hence, an increase in the extent of income-tax progressivity brings about a smaller response in real output to a change in the price level, ceteris paribus, in a nation with a more progressive tax system. 
Following Barro and Gordon (1983), we consider a Nash game involving the central bank and wage setters in which the central bank seeks to minimize the policy loss function,

$$
L=E\left[(y-\hat{y})^{2}+b_{c b} \psi^{2}\right]
$$

where $\hat{y}$ is the nondistorted, full-information economy-wide output under market clearing, $b_{c b}$ is the relative weight that the central bank places on the inflation component of its loss function, and $\psi$ is the $\mathrm{CPI}$ inflation rate. Re-solving the model under full information-that is, with $s^{e}=s, p^{e}=p$, and $m^{e}=m$ ex ante-yields $\frac{-\alpha \beta \lambda \tau_{0}}{\eta\left[\lambda(1-\alpha)+1+\alpha \tau_{1}+\alpha \lambda \beta^{2}\right]}$ to be the full-information output level, which equals zero in a nondistorted situation in which $\tau_{0}=\tau_{1}=0$. Consequently, $\hat{y}=0$. Under the simplifying assumption that $p_{-1}=s_{-1}=0$, the CPI inflation rate is $\psi=(1-\beta) p+\beta s$. Minimizing (16) with respect to $\mathrm{m}$ and solving for $\psi$ ultimately yields

$$
\begin{aligned}
\psi= & \left(\frac{b_{c b} A\left(\eta-\beta^{2}\right)\{(\lambda+1)(1-\alpha)+\alpha \Omega[\lambda(1-\alpha)+1]\}-\lambda \alpha^{2}(1-\alpha) \eta \Omega[\lambda(1-\alpha)+1]}{b_{c b} A[\lambda(1-\alpha)+1][1-\alpha(1-\Omega)]}\right) \\
& \times\left(\frac{\lambda \alpha(1-\alpha)}{\eta(1-\alpha)[\lambda(1-\alpha)+1]+\lambda \alpha(1-\alpha)\left(\eta \tau_{1}+\beta^{2}\right)}\right) \tau_{0}
\end{aligned}
$$

where $A \equiv\left[\eta(1-\alpha)+\beta^{2} \Omega \alpha\right][\lambda(1-\alpha)+1]+(1-\Omega) \lambda \alpha\left(\eta \tau_{1}+\beta^{2}\right)$.

An immediate implication of (13) is that $\frac{\partial \psi}{\partial \tau_{1}}<0$, so that an increase in the degree of progressivity of the tax system unambiguously reduces the equilibrium inflation rate under discretion. An increase in tax progressivity makes output less sensitive to changes in the price level, which in turn reduces the incentive to increase money growth in an effort to raise the price level in an effort to boost output. As a consequence, money growth and CPI inflation are lower, ceteris paribus, when the tax system is more progressive. 
Further evaluation of the expression for $\frac{\partial \psi}{\partial \tau_{1}}$ indicates that either an increase in $b_{c b}$ or in a rise in $\beta$ causes the absolute value of this derivative to decrease. An increase in the relative weight placed on inflation, $b_{c b}$, in the central bank's loss function reduces inflation, so the marginal effect on inflation of greater tax progressivity is lower at larger values of $b_{c b}$. As in Daniels and VanHoose (2006) and Daniels et al. (2005), the direct effect of greater openness $(\beta)$ is to increase the sensitivity of output with respect to the price level, so an increase in $\beta$ tends to counter the effect of greater tax progressivity on inflation, thereby reducing the absolute value of $\frac{\partial \psi}{\partial \tau_{1}}$.

In general, both the direct effect of greater openness and the effects of changes in the sensitivity of inflation with respect to openness resulting from variations in the degree of tax progressivity or the central bank's loss weight on inflation depend on relative magnitudes of parameter values. Evaluation of the direct effect of an increase in the degree of openness, $\beta$, on inflation yields sufficient, but unnecessary, conditions for greater openness to reduce inflation $\left(\right.$ that is, $\left.\frac{\partial \psi}{\partial \beta}<0\right)$ : (1) most of the weight in the loss function is on the inflation objective (a sufficiently large value of $b_{c b}$ ) or (2) the marginal propensity to import is sufficiently larger than the sensitivity of expenditures with respect to the real exchange rate $\left(\beta^{2}>\eta\right)$. If $\frac{\partial \psi}{\partial \beta}<0$, then it is also true that an increase in either $\tau_{1}$ or in $b_{c b}$ generate reductions in the absolute magnitude of this derivative; that is, in this case, either a greater degree of progressivity of the tax system or an increased policy weight on inflation tend to reduce the effect of increased openness on inflation.

The reason for the potential ambiguity in the inflation effects of openness is that greater openness exerts two conflicting effects. On one hand, as in Daniels and VanHoose (2006) and Daniels et al. (2006), because labor supply depends on the real wage computed in terms of the overall price that workers pay for a basket of both 
domestic and foreign goods, a real depreciation of the home currency reduces the purchasing power of market-clearing wages, which generates a ceteris paribus fall in labor supply that, in turn, causes a decline in spot-market employment. Thus, the output of firms without wage contracts responds negatively to a real depreciation of the home currency, and this effect is enhanced in a more open economy, ultimately implying that a greater degree of openness causes output to be more responsive to inflation. This, in turn, tends to increase the incentive for the central bank to push up money growth and generate higher equilibrium inflation.

On the other hand, increased openness reduces the extent to which an unanticipated real depreciation can potentially generate an increase in output. To see this, note that (2) implies, under the maintained assumption $p^{*}=0$, that, ex ante, aggregate expenditures are given by $y=\beta^{-1} \eta(s-p)$. An increase in the value of the marginal propensity to import, $\beta$, relative to the sensitivity of expenditures with respect to the real exchange rate, $\eta$, thereby reduces the extent to which changes in the real exchange rate brought about my variations in the money stock can affect aggregate demand, ex ante. This, in turn, reduces the incentive for a discretionary central bank to increase money growth.

On net, therefore, the ex post effect of greater openness on equilibrium inflation is ambiguous in the present model, although as noted above, it is more likely to be negative if $\beta^{2}>\eta$. As noted above, from an ex ante perspective, a sufficiently higher initial value of the marginal propensity to import relative to an initial value of the expenditure responsiveness to the real exchange rate reduces the extent to which a monetary expansion can boost output via a discretionary increase in money growth. At the same time, because $\mathrm{CPI}$ inflation is $\psi=p+\beta(\mathrm{s}-p)$, a rise in the magnitude of $\beta$ also has the effect of enlarging the extent to which the real exchange rate plays a role in determining equilibrium CPI inflation, which increases the ex ante incentive for the 
central bank to reduce money growth. This explains why if $\beta$ is sufficiently large relative to $\eta$, increased openness is more likely to reduce equilibrium inflation.

\section{Empirical Implications and Evidence}

Following are the empirical implications of the forgoing discussion:

i) increased income-tax progressivity reduces the equilibrium inflation rate;

ii) the effect of increased income-tax progressivity on inflation is smaller when the central bank places a higher weight on inflation or when there is greater openness; and

iii) the effect of greater openness on inflation is generally empirically ambiguous, but if this effect is negative, then it is absolutely smaller due to increased income-tax progressivity or when the central bank places a higher weight on inflation.

To measure the degree of income-tax progressivity (Tax) for individual nations, we use the ratio of the marginal tax rate to the average tax rate. The marginal tax rate is measured by the change in single employees' social security contribution and personal income tax payments in response to a change in gross wage earnings. The average tax rate is the level of social security and tax payments divided by the level of gross wage earnings. Both the marginal tax rate and the average tax rate are from Source OECD. ${ }^{1}$

We use the measure of central bank independence described above along with the inflation rate, which is based on the GDP deflator, and openness, expressed as the ratio of imports to GDP, both derived from the IMF International Financial Statistics. Table 1 contains descriptive statistics on the sample data.

Table 2 reports regression results for an annual sample of 17 countries covering the period 1979-1999. ${ }^{2}$ Because of the time-series nature of this data set, all regressions are estimated using OLS with robust standard errors and correcting for 
serial correlation using the Newey-West procedure. Column (1) of the table provides results for the base specification that controls only for central bank independence and openness. The coefficients for both variables are negative and statistically significant (although the $p$-value for openness is 8.4 percent).

Column (2) of Table 2 reports a re-specification in which the tax progressivity measure is added. The estimated coefficient for the Openness variable is not statistically significant in this specification. The tax progressivity (Tax) coefficient, however, is negative and statistically significant, consistent with the theoretical model's key implication that increased income-tax progressivity reduces the equilibrium inflation rate.

The regression specification in column (3) of Table 2 adds interactions of tax progressivity and central bank independence $\left(\operatorname{Tax}{ }^{*} \mathrm{CBI}\right)$ and for tax progressivity and openness (Tax*Openness). The estimated negative Openness coefficient is once again statistically significant (with a p-value of 6.5 percent) in this broadened specification. The interaction term between tax progressivity and central bank independence is also statistically significant and positive, consistent with the theoretical model's prediction that the (negative) effect of greater income-tax progressivity on inflation is smaller with greater central bank independence (assumed consistent with a higher central bank loss weight on inflation). Consistent with the theoretical framework's implication that the (negative) effect of greater income-tax progressivity on inflation is smaller with greater openness, the estimated coefficient on the interaction term between tax progressivity and openness is positive (indicating a absolute smaller effect of tax progressivity), but this coefficient is statistically insignificant.

Column (4) in Table 2 considers the impact that outliers might have on the results. To test for outliers, we use the dfits test, Cooksd test, and the Welsch distance test on the regression model in column (3). The results for all three tests imply outliers in 1980 and 1982 for New Zealand, and in 1980 for the United States. These three 
observations are deleted from the specification in column (3) to generate the results in column (4). Controlling for these outliers has no practical impact on our results.

According to hypothesis (iii) implied by theoretical framework, if openness is statistically significant and negative, then its effect becomes absolutely smaller as the degree of tax progressivity increases. Consistent with this hypothesis, the estimated coefficient on $\operatorname{Tax}^{*}$ Openness is consistently positive, but it is never significant at a level of 10 percent or less. To further explore the third hypothesis, we also added an interaction term between central bank independence and openness in specification (4). The only resulting changes are a positive but statistically insignificant effect of openness on inflation and an improvement in the $p$-value of the $T a x^{*} \mathrm{CBI}$ interaction variable, to 2.8 percent. In addition, the estimated effect of the openness-CBI interaction term is negative and significant at the 10 percent level. Hence, there is some support for the theoretical prediction that the impact of openness on inflation is empirically ambiguous once the degrees of income-tax progressivity and central bank independence are taken into account.

We also consider some recent results regarding the relationship between openness and inflation. According to Levin and Piger (2002) and Ihrig and Marquez (2003), time-series inflation data exhibit a break around the late 1980s and early 1990s. Bleaney (1999) further notes that around the time of this same break, the economic and statistical significance of the openness-inflation relationship began to diminish among developing nations. Including a dummy variable with a value of zero up until 1989 and a value of unity for the remainder of the sample period had little impact on our results. The $p$-value for $T a{ }^{*} \mathrm{CBI}$ increased slightly, and the $p$-value for $\operatorname{Tax}^{\star}$ Openness decreased somewhat, moving both into the 10 to 15 percent significance range. ${ }^{3}$ 


\section{Conclusion}

This paper has developed an open-economy framework indicating that the structure of the tax system should worsen the terms of the output-inflation trade-off and reduce the equilibrium inflation rate. Analysis of the inflation rates of seventeen nations provides support for our predictions regarding direct and interactive effects of incometax progressivity, openness, and central bank independence on inflation.

The role of taxation as a factor influencing the interactions among openness, central bank independence, and inflation rates has not received attention in the literature. The theoretical and empirical conclusions of this paper indicate that more consideration should be given to the role of fiscal variables as factors conditioning equilibrium inflation rates in open economies. 


\section{REFERENCES}

Bade, Robin, and Michael Parkin, 1982, Central bank laws and monetary policy, Unpublished Manuscript, University of Western Ontario.

Ball, Laurence, 1994. What determines the sacrifice ratio? In: Mankiw, N.G. (Ed.) Monetary Policy. University of Chicago Press: Chicago, IL, pp. 155-193.

Barro, Robert, and David Gordon, 1983, A positive theory of monetary policy in a natural rate model. Journal of Political Economy 91, 589-610.

Benavie, Arthur, and Richard Froyen, 1986, A balanced-budget constraint in modern macromodels, Southern Economic Journal, 53, 247-258.

Bleaney, Michael, 1999, The disappearing openness-inflation relationship: A crosscountry analysis of inflation rates, IMF Working Paper WP/99/161, December.

Bryson, Jay, Henrik Jensen, and David VanHoose, 1993, Rules, discretion, and international monetary and fiscal policy coordination, Open Economies Review 4 (2), 117-132.

Canzoneri, Matthew, and Dale Henderson, 1991, Monetary Policy in Interdependent Economies: A Game Theoretic Approach. MIT Press, Cambridge, MA.

Cukierman, Alex, 1992, Central Bank Strategy, Credibility and Independence: Theory and Evidence, Cambridge MA: MIT Press.

Daniels, Joseph, Farrokh Nourzad, and David VanHoose, 2005, Openness, central bank independence, and the sacrifice ratio, Journal of Money, Credit, and Banking, 37, 371-379.

Daniels, Joseph, Farrokh Nourzad, and David VanHoose, 2006, Openness, centralized wage bargaining, and inflation," European Journal of Political Economy,.

Daniels, Joseph, and David VanHoose, 2006, Openness, the sacrifice ratio, and inflation: Is there a puzzle?" Journal of International Money and Finance, 25, 1336-1347. 
Duca, John, and David VanHoose, 2001. The rise of goods-market competition and the fall of wage contracting: endogenous wage contracting in a multisector economy. Journal of Macroeconomics 23 (1), 1-29.

Franzese, Robert, Jr., 2002, Macroeconomic Policies of Developed Democracies, Cambridge, UK: Cambridge University Press.

Grilli, Vittorio, Donato Masciandaro, and Guido Tabellini, 1991, Political and monetary institutions and public financial policies in the industrial countries, Economic Policy, 13, 341-392.

Ihrig, Jane, and Jaime Marquez, 2003, An empirical analysis of inflation in OECD countries, International Finance Discussion Paper No. 765, Board of Governors of the Federal Reserve System, May 2003.

Lane, Philip, 1997, Inflation in open economies, Journal of International Economics 42, 327-347.

Levin, Andrew, and Jeremy Piger, 2002, Is inflation persistence intrinsic in industrial economies? Federal Reserve Bank of St. Louis Working Paper 2002-023C.

McCallum, Bennett, and John Whitaker, 1979, The effectiveness of fiscal feedback rules and automatic stabilizers under rational expectations, Journal of Monetary Economics, 5, 171-186.

Razin, Assaf, and Prakash Loungani, 2005, Globalization and equilibrium outputinflation trade-offs," NBER International Seminar on Macroeconomics, September 2005.

Razin, Assaf, and Chi-Wa Yuen, 2002, The 'new Keynesian' Phillips curve: Closed economy versus open economy," Economics Letters, 75, 1-9.

Romer, David, 1993, Openness and inflation: Theory and evidence," Quarterly Journal of Economics, 108, 869-903.

Temple, Jonathan, 2002. Openness, inflation, and the Phillips curve: a puzzle. Journal of Money, Credit, and Banking 34 (2), 450-468. 
Waller, Christopher, and David VanHoose, 1989, Endogenous wage indexation and optimal monetary policy with and without a balanced budget, Journal of Economics and Business, 41, 21-31. 
Table 1

Descriptive Statistics for Data Used to

Test Predictions Regarding Inflation

Annual Panel of 17 Countries, 1970-1999a

\begin{tabular}{|l|c|c|c|c|}
\hline & Inflation & $\begin{array}{c}\text { Tax } \\
\text { Progressivity }\end{array}$ & $\begin{array}{c}\text { Central Bank } \\
\text { Independence }\end{array}$ & Openness \\
\hline Mean & 4.63 & 1.17 & 51.46 & 29.79 \\
\hline Median & 3.38 & 1.44 & 47.38 & 28.80 \\
\hline St. Dev. & 3.86 & 0,85 & 19.21 & 13.44 \\
\hline
\end{tabular}

${ }^{a}$ Australia, Austria, Belgium, Canada, Denmark, Finland, France, Germany, Italy, Japan,

Netherlands, New Zealand, Norway, Sweden, Switzerland, United Kingdom, and United States 
Table 2

Inflation Estimates

Annual Panel of 17 Countries, 1970-1999

(Absolute Values of t-Ratios Based on Newey-West Robust Standard Errors in Parentheses)

\begin{tabular}{|c|c|c|c|c|}
\hline & (1) & (2) & (3) & $(4)^{a}$ \\
\hline Constant & $\begin{array}{c}9.097^{\star * \star} \\
1.062\end{array}$ & $\begin{array}{c}9.506^{* * \star} \\
1.019\end{array}$ & $\begin{array}{c}16.345^{\star * *} \\
2.935\end{array}$ & $\begin{array}{c}15.071^{\star * \star} \\
2.769\end{array}$ \\
\hline CBI & $\begin{array}{c}-0.062^{* \star *} \\
0.0132\end{array}$ & $\begin{array}{c}-0.062^{* * *} \\
0.013\end{array}$ & $\begin{array}{c}-0.168^{* * *} \\
0.057\end{array}$ & $\begin{array}{c}-0.149^{* \star \star} \\
0.053\end{array}$ \\
\hline Openness & $\begin{array}{l}-2.904^{*} \\
1.675\end{array}$ & $\begin{array}{c}-1.665 \\
1.806\end{array}$ & $\begin{array}{l}-5.978^{*} \\
3.232\end{array}$ & $\begin{array}{c}-5.418^{\star \star} \\
3.046\end{array}$ \\
\hline Tax & & $\begin{array}{c}-0.702^{\star * *} \\
0.226\end{array}$ & $\begin{array}{c}-4.757^{\star * *} \\
1.636\end{array}$ & $\begin{array}{c}-4.157^{\star * *} \\
1.553\end{array}$ \\
\hline Tax*CBI & & & $\begin{array}{c}0.064^{\star *} \\
0.031\end{array}$ & $\begin{array}{l}0.054^{*} \\
0.029\end{array}$ \\
\hline Tax^Openness & & & $\begin{array}{l}1.742 \\
1.616\end{array}$ & $\begin{array}{l}1.640 \\
1.523\end{array}$ \\
\hline F Statistic & 14.50 & 15.07 & 10.55 & 28.42 \\
\hline Observations & 357 & 357 & 357 & 354 \\
\hline
\end{tabular}

${ }^{*}$ Significant at $10 \%$ level, ${ }^{* *}$ significant at $5 \%$ level, ${ }^{* * *}$ significant at $1 \%$ level.

${ }^{a}$ The model in column 4 omits three outliers; 1980 and 1982 for New Zealand and 1980 for the United States. 
Appendix 


\section{FOOTNOTES}

${ }^{1}$ During the 1979-1993 interval, the OECE reports tax rates only for odd years. For this period, missing observations on the tax rates were imputed using the average of the two adjacent rates. All of the data used in this paper and all regression results are available upon request.

${ }^{2}$ The countries are Australia, Austria, Belgium, Canada, Denmark, Finland, France, Germany, Italy, Japan, Netherlands, New Zealand, Norway, Sweden, Switzerland, United Kingdom, and United States.

${ }^{3}$ Overall, the effect of openness on inflation shows the greatest sensitivity to model specification and controls for model breaks and outliers. 